\title{
Unnatural narratives, unnatural narratology: Contributions, problems and perspectives
}

Récits non naturels, narratologie non naturelle : apports, problèmes et perspectives

Sylvie Patron

Translator. Mark Bossanyi

\section{(2) OpenEdition}

\section{Journals}

Electronic version

URL: https://journals.openedition.org/pratiques/10324

DOI: $10.4000 /$ pratiques. 10324

ISSN: 2425-2042

Publisher

Centre de recherche sur les médiations (CREM)

\section{Electronic reference}

Sylvie Patron, "Unnatural narratives, unnatural narratology: Contributions, problems and perspectives", Pratiques [Online], 181-182 | 2019, Online since 15 January 2021, connection on 03 September 2021.

URL: http://journals.openedition.org/pratiques/10324 ; DOI: https://doi.org/10.4000/pratiques.10324

This text was automatically generated on 3 September 2021.

() Tous droits réservés 


\section{Unnatural narratives, unnatural narratology: Contributions, problems and perspectives}

Récits non naturels, narratologie non naturelle : apports, problèmes et perspectives

Sylvie Patron

Translation : Mark Bossanyi

1 The study of unnatural narratives, or unnatural narratology, is one of the latest trends that have emerged within post-classical narratology. ${ }^{1}$ This approach seems innovative and promising as it links in with several current questions associated with theory, analysis and the interpretation of fictional narratives. It has also been intensely discussed within the narratological milieu. Far from being a unified approach, unnatural narratology involves different trends, based on slightly different definitions of unnatural narratives, which sometimes lead to advocating for very different and even opposing approaches to these narratives. Unnatural narratology has already made important contributions in the study of unnatural narratives or unnatural elements in narratives that are usually neglected in established narratology or narratologies. However, further investigation reveals certain problems, a significant example of which is presented at the end of the article.

\section{Unnatural narratology: a brief history of the movement}

2 If we search for discussions on, and possibly the steps that led to the emergence of, unnatural narratology, what appears first concerns the name itself. An article by Henrik Skov Nielsen published in 2011 contains these lines:

After the ISSN Conference on Narrative in Washington in 2007, a small group incidentally gathered in the lobby. The group included Brian Richardson, Jan Alber, Maria Mäkëlä and me. We realised that the conference in Washington seemed to have yielded a rather strong resistance to otherwise predominant naturalising 
paradigms. Consequently, we invited everyone interested to join a group on what we tentatively called "unnatural narratology." (2011a, p. 55, n. 2 reproduced in 2011b, p. 71)

3 "Unnatural narratology" is in opposition to "natural" narratology as understood by Monika Fludernik (see 1996). ${ }^{2}$ Others went on to criticise unnatural narratologists for not using the quotation marks, pointing out that "unnatural" had negative or stigmatising connotations. The responses from unnatural narratologists were always very clear: unnatural narratology is not part of the debate between nature and culture and is not describing any social practice or any specific kinds of behaviour as natural or unnatural. The term "unnatural" must be understood within the full context of narratology research and in this context only has positive connotations (see Alber \& Heinze, 2011a, p. 2; Alber, Nielsen \& Richardson, p. 374; Richardson, 2012b, p. 98; Alber, Iversen, Nielsen \& Richardson, 2013b, p. 4; Richardson, 2015, p. 6 and 2016a, p. 393). After this event in the lobby, unnatural narratologists bought a website address, www.unnaturalnarratology.com, ${ }^{3}$ which contributed to the on-going use of the name unnatural narratology.

Unnatural narratology quickly gained notoriety in academia with the organisation of panels at ISSN conferences and other international conferences, ${ }^{4}$ and the publication of a manifesto, "Unnatural narratives, unnatural narratology: Beyond mimetic models," written by Jan Alber, Stefan Iversen,

Henrik Skov Nielsen, and Brian Richardson (see Alber et al., 2010). ${ }^{5}$ Currently, the field includes two major collective works (Alber \& Heinze, 2011b; Alber, Nielsen \& Richardson, 2013), ${ }^{6}$ and two monographs (Richardson, 2015; Alber, 2016), to which we can add all chapters written by Richardson in Herman et al. (2012), two issues or issue sections of academic journals (Style, 2016; Storyworld, see Richardson, 2017b) ${ }^{7}$, an online dictionary (http://projects.au.dk/narrativeresearchlab/unnatural/undictionary), as well as a huge number of individual or collective articles dedicated to unnatural narratives or to unnatural elements in narratives.

\section{What is an unnatural narrative? Slightly differing definitions}

Richardson (2015, p. 3, reproduced in 2017a, p. 193 and 2018, p. 167) defines an unnatural narrative as "a narrative that contains significant antimimetic events, characters, settings, or frames". By antimimetic, "[he] mean[s] representations that contravene the presuppositions of non-fictional narratives, violate mimetic expectations and the practices of realism, and defy the conventions of existing, established genres." ${ }^{\prime 8}$ Let's take look at these terms. Mimetic: that which copies or significantly resembles non-fictional narratives. Mimetic narratives try to represent the real world in a recognisable way. According to Richardson, narratology is based on these narratives and is thus affected by a mimetic bias that limits its ability to explain and describe. Antimimetic: that which diverges in different ways (fun, critical, etc.) from the mimetic project or system. Richardson makes an additional distinction between antimimetic and what he calls non-mimetic. An antimimetic narrative, such as Molloy by Samuel Beckett, defies the conventions of mimetic representation. Non-mimetic narratives like fairy tales, animal fables or ghost stories build a coherent, fictional, 
parallel world to the real world. This new world has its own laws, conventions and codes. In certain cases, the narratives include additional supernatural elements to representations that remain predominantly mimetic compared to the real world. Only antimimetic narratives have a surprise effect on the reader or, if we were to use the term by Russian formalists often cited by Richardson, they create a "defamiliarisation" effect (see for example Richardson, 2015, p. 24 and 2016b, p. 509). Richardson also made the comment that many narratives are completely mimetic, but none can by completely antimimetic. However, both aspects can be found simultaneously, to differing degrees in a number of narratives. Mimetic narratives generally try to hide their artificial nature (or artefactual nature) while, on the other hand, antimimetic narratives frequently attract attention to their fictional status, even highlighting how they are created. Antimimetic elements (events, characters, etc.) are often more remarkable or more interesting when they are understood through a logical, dialectic relationship with mimetic aspects of the narrative in which they appear (see Richardson, 2015, p. 4).

6 In the definition by Richardson, unnatural is therefore linked with the term antimimetic. Richardson insists specifically on the fact that "conventional non-mimetic works are not, from [his] perspective, unnatural narratives" (2015, p.4); or based on another phrase, "unnatural fiction is different, not only from mimetic fiction, but also from what [he] calls non-mimetic [...] fiction [...]" (2016a, p. 386). Paradigmatic examples of unnatural narratives for Richardson are the non-realist narratives of Jorge Luis Borges (such as, "The Aleph"), The Unnamable by Beckett and Jealousy by Alain Robbe-Grillet, which he often mentions. For him, unnatural narratives also include Ice by Anna Kavan, Midnight's Children by Salman Rushdie, which he analyses in detail (Richardson, 2012a), or even The Satanic Verses by the same author. Richardson emphasises that unnatural narratives are encountered in almost all periods of Western literary history. He also points out that it is possible to find their equivalents in other cultures (see 2015, chap. 5 and pp. 5, 10 and passim).

7 Jan Alber (2016, p. 14) defines unnatural narrative as presenting "physically, logically, and humanly impossible scenarios [...]". By "physically impossible", he means impossible based on the fundamental laws that govern the physical world. By "logically impossible", he means impossible based on the principles of logic, in particular the law of non-contradiction. These two definitions are borrowed from Lubomír Doležel (1998, p.115) in his presentation on natural and supernatural worlds in fiction. The definitions appear in the first works of unnatural narratology by Alber $(2009$, p. 80, quoted in Alber et al., 2010, p. 115; Alber \& Heinze, 2011a, pp. 4-5). Starting from 2012, Alber also adds "humanly impossible" which for him means impossible given the limits of human knowledge and ability (see Alber, Nielsen \& Richardson, 2012, p. 351; Alber et al., 2012, p. 373; Richardson, 2012b, p. 98; Alber et al., 2013a, p. 102; 2013b, p. 6; Alber, 2013b, p. 449; 2013d, § 1 and 3).

8 Alber's definition is paradoxically both more restrictive and broader than that of Richardson. The latter recognizes that he is referring to "odd", "unusual", "anomalous", as well as strictly "impossible" phenomena. For Richardson, the criterion for identifying the unnatural is the effect of surprise or defamiliarisation that it creates in the reader. For Alber, however, the criterion for unnatural is internal to the text or more specifically to the fictional world projected by the text. He is thus referring to the presence of impossible scenarios and events that cannot be produced in the real world 
(see Alber, 2016, pp. 3, 16, 29, 32 and 41). Yet, Alber also has a broader definition than Richardson, who excludes conventional non-mimetic works, such as fairy tales, animal fables and ghost stories from his field of study. Alber examines such conventional, nonmimetic works in detail (see for example 2011; 2013a; 2013b; and especially 2016). He compares the physical, logical or human impossibilities of postmodernism that have yet to be conventionalised, meaning those elements that have not been transformed into standard, cognitive frames, with those that have been conventionalised, such as talking animals in fables or children's stories, the ghosts and vampires in Gothic novels, the witches in "fantasy" literature, and time travel in science-fiction novels.

Paradigmatic examples of unnatural narratives for Alber include Time's Arrow by Martin Amis, where time flows backwards (from the future to the past), and "The Babysitter", a short story by Robert Coover, which describes many contradictory scenarios. He also includes Midnight's Children, for its representation of human impossibility (the narrator, Saleem Sinai, literally hears the thoughts of other people).

The definition of unnatural narratives according to Nielsen is at first glance very similar to that of Alber. For him they are a subset of fictional narratives that, "[...] may have temporalities, storyworlds, mind representations, or acts of narration that would have to be construed as physically, logically, mnemonically, or psychologically impossible or highly implausible in real-world storytelling situations" (Alber et al., 2013a, p. 104; 2013b, p. 6; Nielsen, 2013, p. 72; 2014, p. 241). ${ }^{9}$ The divergence between Nielsen and Alber appears more clearly in the following section. Nielsen adds that unnatural narratives, "allow readers to interpret them as reliable, possible, or authoritative by cuing them to change their interpretational strategies" (Alber et al., 2013a, p. 104).

11 We could also cite the definition of unnatural minds by Stefan Iversen, (" $[. .$.$] an$ unnatural mind is a presented consciousness that in its functions or realisations violates the rules governing the possible world it is part of in a way that resists naturalisation or conventionalisation", 2013b, p. 97), or Marko Mäkelä, who understands the notion as covering all representations of consciousness in literature ("[...] we do not have to resort to avant-garde literature to realise that the potential unnaturalness - of the peculiarly literary type of cognitive challenge - is always already there in textual representations of consciousness," 2013, p. 133, cited in Alber et al., 2013b, p. 7).

12 Paradigmatic examples of unnatural narratives for Nielsen are narratives like Glamorama by Bret Easton Ellis, who includes multiple moments where the narration from the narrator would be impossible or implausible in the real world. Paradigmatic examples of unnatural narratives for Iversen are "The Metamorphosis" by Frank Kafka or Truismes by Marie Darrieussecq, which presents metamorphosed minds that are both human and animal. One of the problems, however, posed by the definition by Mäkelä is that it does not differentiate those narratives that are natural and those that are unnatural from among fictional narratives. According to her definition, it is thus impossible to give paradigmatic examples of unnatural narratives.

\section{Very different, almost opposing, approaches}

13 Richardson, Nielsen and Iversen are very wary of applying a cognitive approach in their analysis and interpretation of unnatural narratives, since this type of approach tends 
to explain unnatural narratives in terms of standard knowledge and familiar experience. Iversen even speaks about "renaturalisation" ("According to such an interpretive strategy, the job of both the layman and the professional reader is to renaturalise [...]", 2013b, p. 95). In contrast, Alber argues for a cognitive approach to the unnatural, based on patterns (or frames) and scripts which, when kept in mind, are used in daily life to establish links between events. All of his work is focused on identifying and then using, as part of his own analyses and interpretations, the strategies that readers use when confronted with unnatural events or scenarios (strategies that he envisaged to begin with as "naturalisation" strategies", see Alber, 2009 , pp. 81,82 and 83 , before moving on to defining them as "reading strategies" or "navigation tools", reserving the term "naturalisation" for the third strategy, see for example Alber, 2013b, pp. 452 and 458, n. 16; 2013c, p. 49; 2014, p. 274 and n. 18; 2016, p. 51 and p. 237, n. 14). These strategies are heavily inspired by an article written by Tamar Yacobi on interpreting incongruities in fictional narratives (see 1981). 
Nine reading strategies from Jan Alber

1. Blending/ frame enrichment

This strategy involves creating new frames by combining or broadening pre-existing frames, or modifying them to varying degrees.

Examples: the dead narrator, the speaking tree; Philip Roth, The Breast.

2. Generification, evoking conventions from literary history

See the "generic principle" by Yacobi (1981, pp. 115-116).

Examples: speaking animals in fables or children's stories, time travel in science-fiction novels.

3. Subjectification

This strategy involves invoking specific states of conscienceless (dream, fantasy, hallucinations, etc.) for a specific character, who is usually the narrator. This is the only strategy of naturalisation for Alber (since it reveals that what may appear unnatural is in fact totally natural).

See the "perspective principle" by Yacobi (1981, pp. 115-116).

4. Foregrounding a thematic component

Example: the telepathic powers of the narrator in Midnight's Children interpreted as the ability to have mutual understanding between different ethnic groups, religions and communities in post-colonial India.

5. Allegoric reading

Example: "The Metamorphosis" considered as an allegory for the human condition, illustrating how humans can sometimes feel they are being treated like vermin.

6. Satirisation or parody

Example: The Breast.

7. The act of creating a transcendent world

Example: paradise, hell, purgatory; as found in Comedy by Beckett, which is interpreted as referring to purgatory, but without purification.

8. Do it yourself

This strategy involves using the text as a construction kit to create one's own story.

See Ryan (2006, p. 671).

Example "The Babysitter".

9. The Zen way of reading

This strategy is built on rejecting previous explanations and involves accepting the unnatural as is, with the cognitive discomfort or pleasure that it may evoke (e.g., the discomfort inherent in contradiction).

If the first reading strategy seems correct but relatively trivial (Alber himself considers that "this process plays a crucial role in all cases in which we attempt to give meaning to the unnatural", Alber et al., 2013a, p. 116, n. 8), a certain number of other strategies arise merely from the choice made by Alber to include within his definition of "unnatural narratives" those narratives that Richardson calls non-mimetic and which he excludes from study. We should remember that for Iversen, unnatural narratives (the unnatural minds in narratives) are those that resist naturalisation and conventionalisation, terms which correspond precisely to Alber's third and second (associated with the fifth) reading strategies. Alber and Iversen also differ in their interpretation of "The Metamorphosis" which, according to the former, lends itself to an allegoric reading (see Alber, 2011, p. 56), while the later states the opposite. He 
found that it is not easy to make such a reading and considers that the interest in the text lies elsewhere (see Iversen, 2013b, p. 106; see also Richardson, 2016b, p. 507).

Nielsen asserts the legitimacy of what he calls "unnaturalising" readings of unnatural narratives: "[...] the reader has the option to try to maximise relevance by applying a qualitatively different set of interpretational rules. For example, the reader can strategically assume that it makes sense to trust those narrative details that a first person narrator cannot possibly know" (2011b, p. 79). "An unnatural approach [...] admits that the reader can represent such situations as descriptions of the reliable authoritative matter-of-fact fictional universe" (2014, p. 241); “[...] an unnaturalising reading is an interpretational choice that, unlike naturalising readings, does not assume that real world conditions and limitations have to apply to all fictional narratives when it comes to logic, physics, time, enunciation, framing, etc." (ibid.). In contrast to the reading strategies of Alber, those of Nielsen specifically involve excluding those naturalising interpretations that are found to be irrelevant (e.g., interpreting a text by considering the narrator to be unreliable in certain passages of a first-person narrative). Moreover, Alber criticises Nielsen for not properly handling the concepts of interpretation or creation of meaning as he had defined them (see Alber, 2013b, p. 455; 2014, pp. 261 and 265; 2016, p. 18).

The final reading strategy of Alber, the Zen reading strategy, may be considered as a way of integrating into his system the critical aspect found in the description of unnaturalising reading strategies from Nielsen (see Alber, 2009, p. 83 and 2013b, p. 454, etc.). It should be noted however that this strategy is never mentioned by Nielsen. Richardson also denies that Nielsen, Iversen and himself have a "Zen-like" approach (2016a, p. 401).

\section{Several achievements in unnatural narratology}

Richardson proposed a categorisation for unnatural temporalities, often cited in unnatural narratology works (see Richardson, 2002, reproduced in 2011a, pp. 59-60; 2012a, pp. 77-78; 2013, p. 21; 2015, pp. 56-57; 2017a, pp. 196-199; quoted in Alber et al., 2010, pp. 115 and 116; Alber \& Heinze, 2011a, pp. 7-8; Heinze, 2013, p. 32, n. 1, 40; Alber, 2016, p. 149). According to Richardson, fictional temporalities can be circular (as found in The Circle by Vladimir Nabokov); contradictory (as in The Babysitter), antinomic (as in Time's Arrow) differential (when time passes at different speeds for different characters, as found in Orlando by Virgina Woolf or Cloud Nine by Caryl Churchill); combined or mixed (as in Passacaglia by Robert Pinget); dual, or multiple, and can even unfold according to unknown laws (such as with "a long minute of six hundred and thirty five days" in the chapter of the Sundarbans in Midnight's Children). ${ }^{10}$ In all these cases, Richardson observes that the narratological categories inherited from Gerard Genette (order, duration, frequency as well as in certain cases, analepsis or prolepsis, etc.) cannot be applied or can only be applied with significant precautions.

Alber dedicated an article to unnatural spaces that, according to his definition, are physically or logically impossible (see 2013c, reproduced in 2016, chap.5). a good example of which is the house in House of Leaves by Mark Z. Danielewski. This is a house of which the internal architecture is transformed while its owners were away. It is wider inside than it is when measured from outside and has corridors that change size, becoming labyrinths, where compasses are useless, etc. Alber proposes an explanation 
for the unnatural space in the house using the fifth reading strategy, the allegoric reading. According to him, the house represents the absurdity or meaninglessness that can invade all human relationships. The labyrinth of the house ends the sex life of Karen and Will Navidson and leads to "impatience, frustration, and increasing familial alienation" (Danielewski, quoted in Alber, 2013c, p. 61 and 2016, p. 190). The house becomes a representation of the hostile world that systematically destroys interpersonal relationships. It should be noted that the novel describes itself using subjectification in reference to a character (third reading strategy) before going on to reject this reading: "Certain people have suggested that the horrors Navidson described in this house were simply manifestations of his own confused psyche" (Danielewski, 2015, p. 21).

Iversen is known for his works on unnatural minds (see 2011, 2013a and 2013b). In Iversen (2013b), he focuses on a specific case, which is the "metamorphosed mind", an abbreviation for the human mind metamorphosed into an animal. An example of this is found in The Metamorphosis; however, he chooses to develop the one used in Truismes. He shows how, "this form of narrative dislocates the distinction between the mind as an intramental phenomenon and the mind as a social phenomenon in an instructive way [...]" (ibid, p. 109). In those areas where it might be expected to find inner thoughts, feelings and motivations, we encounter public language, everyday expressions, and clichés. Where we would expect to find social cognition phenomena, such as the recognition of facial emotions, we actually encounter fear and rejection in front of the protagonists' bizarre appearance.

Nielsen is essentially interested in acts of unnatural narration. He focuses more on acts or ways of narration that are "odd", "unusual", and "anomalous", rather than strictly "impossible", as is shown in his comment on first-person narration in the present tense:

"Right, there is no "occasion of narration" and this is a slightly paradoxical situation, but to describe this as the narrator "doing the impossible - living and telling at the same time" runs the risk of placing the paradox and the impossibility at the story level as if this was a story about a character capable of the impossible. I would prefer to say (and I think this is maybe also what Phelan means) that we have to just accept this act of narration even though it is an impossible real world narrative act." (Nielsen 2011a, p. 65; the quotes are taken from Phelan, 1994, pp. 233-234.)

21 Some of the subjects covered in articles by Nielsen include first-person narration in the present tense (or narration in the "fictional present" using Dorrit Cohn's term [2001, p. 164]), narration in the second person, and access to others' thoughts in first-person narration, which I would define as the representation of others' thoughts (see 2010; 2011a; 2011b; 2011c; 2013; 2014). In terms of accessing others' thoughts in first-person narratives, it is important to distinguish, once again, between narratives in which the impossibility is found at a general story level, meaning it is the story of a character capable of the impossible (e.g., S. Sinai in Midnight's Children), and narratives which give access to the thoughts of characters other than those of the narrator, as if the usual conventions of first-person narration were suspended, or a form of editing had been done (e.g., the last thoughts of dying Bergotte in The Prisoner by Marcel Proust or those of the passengers of a plane in the process of exploding in Glamorama, or even chapters XXXVII and XXXVIII of Moby-Dick by Herman Melville). Nielsen is only interested in the second category of narratives. (I would like to emphasise that he does not use the word 
editing nor the hypothesis which are both my own). In his analysis, Nielsen enhances the role of the author, which is totally hidden by the prominence of the narrator and the communication between the narrator and the one being narrated to in narratology.

Whether in reference to time, space, characters or narrators and acts of unnatural narration, the specificity of Alber's work (2016) is to link the unnatural elements of post-modernist narratives to earlier productions on the same elements that are now conventionalised through their association with specific literary genres (animal fables, medieval epics, it-narratives of "circulation novels" from the 18th century, Gothic novels, science-fiction novels, etc.).

\section{Problems in unnatural narratology}

I am not going to cover the problems that have already been identified: contradictions, non-overlapping areas, the disconnect between definitions and approaches in unnatural narratives used by different representatives of unnatural narratology. We might have also noticed problems in the definitions of the narratives that serve as counter-examples. These are Richardon's "non-fictional narratives" and (fictional) mimetic or realist narratives (specifically those that conform to "mimetic expectations [and] to the conventions of realism"), without even touching on conventional, nonmimetic narratives. With Nielsen the difficulty is with the definition of natural narratives meaning those narratives produced naturally, that is, spontaneously in ordinary conversation. These types of narratives do not coincide exactly either. Using a distinction provided by Per Krogh Hansen, we could say that unnatural narratology focuses on two phenomena or groups of phenomena:

- Narratives that move away from natural conversational narratives, as in Fludernik (1996) or Herman (2009).

- "Unnatural" narratives with scenarios and events, such as narration scenarios that are impossible in the real world (see Hansen, 2011, p. 163).

This distinction raises the issue of a possible confusion between the two groups of phenomena. One example that is discussed below is the omniscient narrator. Another problem, which I will not cover here, is that of the pre-eminence of natural conversational narratives whose degree of relevance is worth being redefined.

The theme of omniscience or of the omniscient narrator appears right from the start of work on unnatural narratology. It covers those "techniques and forms" which have been "conventionalised" over the course of time, without being "naturalised" (Alber et al., 2010, p. 131). The distinction between conventionalisation and naturalisation is addressed again by Nielsen (2011b, p. 84-86) and presented once again in Alber, Nielsen and Richardson (2012, p. 352):

[...] [...] even if a narrative technique is highly divergent from real-life parameters, it may be (or become) highly conventional. A good example of this is provided by narratives told by what is often referred to as an "omniscient" third-person narrator who is omnipresent, omnitemporal, and able to provide access to the minds of the characters. [...] Narratives of this kind are unnatural in the specific sense that they correspond to no real-life storytelling situation, but are no longer considered to be experimental or unconventional.

In this quote, the expression "what is often referred to as", as well as the quotation marks around the term "omniscient" demonstrate a certain discomfort with the term. 
Yet, the expression disappears completely in other occurrences (see for example Alber et al., 2013b, p. 6; Alber, 2013d, § 2 and 13; Richardson, 2015, pp. 35-36, 41; Alber, 2016, pp. 88-103).

For a long time omniscient narration was not really an issue for narrative theory. Traditionally, theory did not distinguish the narrator from the author or only envisaged the fictional narrator in the case of memoires or first-person novels in line with the original meaning of the term (see Patron, 2016, pp. 15-19). In this theory, the narrator is evidently not omniscient. First-person narration represents the antithesis of omniscient narration. In novels narrated in the third person, narration is attributed to the author himself. The author is therefore being described as "omniscient". However, omniscience must be considered as an effect of the text and of the nature of the information that it contains. As Genette wrote (2007, p. 348), "the author has nothing to 'know', since he invents everything". The term "omniscient" only became problematic when narratologists, such as Genette to a certain extent but others more readily, started applying it to the fictional narrator supposedly telling actual events. The omniscient narrator must thus be considered as being the product of the hypothesis that all fictional narratives have a fictional narrator. Yet, what type of entity does this narrator represent, where does his omniscience come from? How can he be both fictional, meaning belonging to the same fictional world as the characters, and omniscient?

The problem for Nielsen, Alber and other unnatural narratologists is that they confuse those unnatural elements invented by the authors of fictional narratives with the omniscient narrator, who is an invention of narratology ("...] unnatural scenarios and events that have already been conventionalised and turned into a cognitive category [...], such as "talking animals", the "omniscient" narrator [...]", Alber et al., 2010, p. 131; see also Alber et al., 2013b, p. 6; Alber, 2013a, p. 2138 and n. 5). While it may be useful to discuss elements that have been conventionalised without being naturalised for talking animals in animal fables, not so for the (supposed) omniscient narrator.

Alber goes even further in the ontologisation of the theoretical entity known as the "omniscient narrator". He considers it to be an entity existing in the fictional world and which has attributes like any other fictional entity:

Despite the desire to move away from the supernaturalism of romance, the omniscient narrator of realist novels and the narrative medium in reflective narratives found in literary modernism also imply a certain degree of magic. Like wizards (such as Merlin), these narrators or narrative media are capable of telepathy. In contrast to real-world agents, they can literally read the minds of other characters (see also Alber 2013a) (Alber, 2013d, § 13).

Like magicians or wizards, narrators or third-person voices in certain types of fiction (modernist) are capable of omnimentality. They have access to the minds of other characters, satisfying the desire shared by all people to know the thoughts and feelings of their peers. In this way, these early types of fiction transcend the parameters of the real world, exactly as post-modernist narratives do (Alber, 2016, p. 103).

In this hypothesis, realist novels, such as those of Gustave Flaubert or a modernist novel such as Mrs Dalloway by Woolf, often cited by Alber (see 2011, pp. 57-58; 2013a, pp.146-147; 2016, pp.97-98), become closely linked to medieval fairy tales, to the heroic poems of the Italian Renaissance, or even, if we extrapolate a little, to The Indiscreet Jewels of Denis Diderot. ${ }^{11}$ 
31 For Alber, the example of Midnight's Children, in which there is a fictional narrator gifted with the fictional ability to literally hear the thoughts of other characters, (“ [...] I reiterate, entirely without a sense of shame, my unbelievable claim: after a curious accident in a washing-chest, I became a sort of radio" Rushdie, 1989, p. 241) is systematically confused with examples from realist or modernist novels, which appear to have been given by narratology an omniscient narrator, which has no imaginative reality for the reader (see Alber, 2013a, pp. 137, 138, 143 and 147; 2016, pp. 25, 81 and 88).

Unnatural narratology must work to clarify its relationship with the notions of fiction and fictional truth (it is fictionally true that the story of Midnight's Children is told by a telepathic narrator, "a sort of walking radio antenna"; it is not fictionally true that Mrs Dalloway is told by an omniscient narrator). The field has to be more careful and critical, taking into consideration the complexity of what Gregory Currie (2010, p. 59) called "the limitation of representational correspondence". This means that "for a given representational work, only certain features of representation serve to represent features of the things represented" (as we have seen for first-person narration in the present tense but other examples could be cited). I also think that there is extensive work to be done on how unnatural narratives are received in terms of how readers fill in the blanks of the text or conversely are not aware of certain gaps, since these narratives seem to me to have a peculiar relationship with the concept of incompleteness in fictional worlds.

Unnatural narratology must be more vigilant in its desire to be more diachronic. Eva Von Contzen was right to say that unless there are direct or indirect intertextual links, pre-modern narratives do not "foreshadow" (term used by Alber) later works. The idea of foreshadowing involves both teleology and value judgements (see Von Contzen, 2017, in particular p. 9). We cannot settle with merely identifying unnatural elements, such as magicians and fairies, or even the miracles in medieval narratives, independently of their place within a given historical or cultural context (see ibid.).

Unnatural narratology has started to systematically explore the links between the choice of the unnatural and ideology, in a broader sense of the term, over the 20th and 21st centuries (see Richardson, 2015, chap. 7; Richardson, 2017b). There is still too little academic output covering the unnatural in media: films, comics, graphic novels, video games, etc. ${ }^{12}$ These are a few of the perspectives emerging in the future of the field.

\section{BIBLIOGRAPHY}

ALBER, J. (2009). Impossible Storyworlds - and What To Do With Them. Storyworlds 1 (1), pp. 79-96.

ALBER, J. (2011). The Diachronic Development of Unnaturalness: A New View on Genre. In: Alber, J. \& Heinze, R. (eds), Unnatural Narratives-Unnatural Narratology. Berlin: De Gruyter, pp. 41-67. 
ALBER, J. (2013a). Pre-Postmodernist Manifestations of the Un Natural: Instances of Expanded Consciousness in "Omniscient" Narration and Reflector-Mode Narratives". Zeitschrift für Anglistik und Amerikanistik 61 (2), pp. 137-153.

ALBER, J. (2013b). Unnatural Narratology: The Systematic Study of Anti-Mimeticism. Literature Compass 10 (5), pp. 449-460.

ALBER, J. (2013c). Unnatural Spaces and Narrative Worlds. In: Alber, J. et al. (eds), A Poetics of Unnatural Narrative. Columbus: The Ohio State University Press, pp. 45-66.

ALBER, J. (2013d). Unnatural Narrative. In: P. Hühn et al. (eds), The Living Handbook of Narratology. Online: http://www.lhn.unihamburg.de/article/unnatural-narrative.

ALBER, J. (2014). Postmodernist Impossibilities, the Creation of New Cognitive Frames, and Attempts at interpretation. In: Alber, J. \& Hansen, P. K. (eds), Beyond Classical Narration: Transmedial and Unnatural Challenges. Berlin: De Gruyter, pp. 261-280.

ALBER, J. (2016). Unnatural Narrative: Impossible Worlds in Fiction and Drama. Lincoln: University of Nebraska Press.

ALBER, J. \& HEINZE, R. (2011a). Introduction. In: Alber, J. \& Heinze, R. (eds), Unnatural NarrativesUnnatural Narratology. Berlin: De Gruyter, pp. 1-19.

ALBER, J. \& HEINZE, R. (eds) (2011b). Unnatural Narratives-Unnatural Narratology. Berlin: De Gruyter. ALBER, J. \& RICHARDSON, B. (eds) (to be published). Unnatural Narratives: Critical Theory and Cultural Studies. Columbus: The Ohio State University Press.

ALBER, J., CARACCIOlO, M., IVERSEN, S., KUKKONEN, K., \& NIELSEN, H. S. (eds) (to be published). Unnatural and Cognitive Perspectives on Literary Studies: A Theory Crossover. Poetics Today, 39 (1-2).

ALBER, J., IVERSEN, S., NIELSEN, H. S. \& RICHARDSON, B. (2010). Unnatural Narratives, Unnatural Narratology: Beyond Mimetic Models. Narrative 18.2, pp. 113-136.

ALBER, J., IVERSEN, S., NIELSEN, H. S. \& RICHARDSON, B. (2012). What Is Unnatural about Unnatural Narratology? A Response to Monika Fludernik. Narrative 20 (3), pp. 371-382.

ALBER, J., IVERSEN, S., NIELSEN, H. S. \& RICHARDSON, B. (2013a). What Really Is Unnatural Narratology?. Storyworlds 5, pp. 101-118.

ALBER, J., IVERSEN, S., NIELSEN, H. S. \& RICHARDSON, B. (2013b). Introduction. In Alber, J. et al. (eds), A Poetics of Unnatural Narrative. Columbus: The Ohio State University Press, pp. 1-15.

ALBER, J., NIELSEN, H. S. \& RICHARDSON, B. (2012). Unnatural Voices, Minds, and Narration. In: J. Bray et al. (eds), The Routledge Companion of Experimental Literature. London: Routledge, pp. 351-367.

ALBER, J., NIELSEN, H. S. \& RICHARDSON, B. (eds) (2013). A Poetics of Unnatural Narrative. Columbus: The Ohio State University Press.

COHN, D. (2001) [1999]. Le Propre de la fiction. Translation by C. Harry-Schaeffer. Paris: Éditions du Seuil.

CURRIE, G. (2010). Narrative and Narrators: A Philosophy of Stories. Oxford: Oxford University Press. DANIELEWSKI, M. Z. (2015) [2000]. La Maison des feuilles. Translation by Christophe Claro. Paris: Éditions du Seuil.

DOLEžEL, L. (1998). Heterocosmica: Fiction and Possible Worlds. Baltimore: Johns Hopkins University Press. 
FLUDERNIK, M. (1996). Towards a "Natural" Narratology. London: Routledge.

FLUDERNIK, M. (2012). "How Natural Is "Unnatural Narratology"; or What is Unnatural about Unnatural Narratology? . Narrative 20 (3), pp. 357-370.

GENETTE, G. (2007) [xxxx]. Discours du récit. Paris: Éditions du Seuil.

HANSEN, P. K. (2011). Backmasked Messages: On the Fabula Construction in Episodically Reversed Narratives. In: Alber, J. \& Heinze, R. (eds), Unnatural Narratives-Unnatural Narratology. Berlin: De Gruyter, pp. 162-185.

HEINZE, R. (2013). The Whirligig of Time: Towards a Poetics of Unnatural Temporality. In Alber, J. et al. (eds), A Poetics of Unnatural Narrative. Columbus, The Ohio State University Press, pp. 31-44. HERMAN, D. (2009). Basic Elements of Narrative. Malden: Wiley-Blackwell.

HERMAN, D. et al. (2012). Narrative Theory: Core Concepts and Critical Debates. Columbus: The Ohio State University Press.

IVERSEN, S. (2011). In Flaming Flames: Crises of Experientiality in Non-Fictional Narratives. In: Alber, J. \& Heinze, R. (eds), Unnatural Narratives-Unnatural Narratology. Berlin: De Gruyter, pp. 89103.

IVERSEN, S. (2013a). Broken or Unnatural? On the Distinction of Fiction in Non-Conventional First Person Narration. In: Hyvärinen, M. et al. (eds), The Travelling Concept of Narrative. Amsterdam: John Benjamins Publishing, pp. 141-162.

IVERSEN, S. (2013b). Unnatural Minds. In: Alber, J. et al. (eds), A Poetics of Unnatural Narrative. Columbus: The Ohio State University Press, pp. 94-112.

KLAUK, T. \& KÖPPE, T. (2013). Reassessing Unnatural Narratology: Problems and Prospects. Storyworlds 5, pp. 77-100.

MÄKELÄ, M. (2013). Cycles of Narrative Necessity: Suspect Tellers and the Textuality of Fictional Minds. In L. Bernaerts et al. (eds), Stories and Minds: Cognitive Approaches to Literary Narratives. Lincoln: University of Nebraska Press, pp. 129-151.

NIELSEN, H. S. (2010). Natural Authors, Unnatural Narration. In J. Alber \& M. Fludernik (eds), Postclassical Narratology: Approaches and Analyses. Columbus: The Ohio State University Press, pp. 275-301.

NIELSEN, H. S. (2011a). Fictional Voices? Strange Voices ? Unnatural Voices ? . In: Hansen, P. K. et al. (eds), Strange Voices in Narrative Fiction. Berlin: De Gruyter, pp. 55-82.

NIELSEN, H. S. (2011b). Unnatural Narratology, Impersonal Voices, Real Authors, and NonCommunicative Narration. In: Alber, J. \& Heinze, R. (eds), Unnatural Narratives-Unnatural Narratology. Berlin: De Gruyter, pp. 71-88.

NIELSEN, H. S. (2011c). Theory and Interpretation, Narration and Communication, Authors and Narrators - James Frey's A Million Little Pieces as a Test Case. In: Patron, S. (ed.), Théorie, analyse, interprétation des récits/Theory, Analysis, Interpretation of Narratives. Bern: Peter Lang, pp. 73-92.

NIELSEN, H. S. (2013). Naturalizing and Unnaturalizing Strategies: Focalization Revisited. In: Alber, J. et al. (eds), A Poetics of Unnatural Narrative. Columbus: The Ohio State University Press, pp. 67-93. NIELSEN, H. S. (2014). The Unnatural in E. A. Poe's “The Oval Portrait”. In: Alber, J. \& Hansen, P. K. (eds), Beyond Classical Narration: Transmedial and Unnatural Challenges. Berlin: De Gruyter, pp. 239260.

Pratiques, $181-182 \mid 2019$ 
OLSEN, J.-A. (2004). L'Esprit du roman. Euvre, fiction et récit. Bern: Peter Lang.

PATRON, S. (2012). Phrases sans parole. À propos d'une histoire d'amour du xx siècle. CMLF 2012, $3^{\mathrm{e}}$ Congrès mondial de linguistique française, Lyon, 4-7 July. Online: http://www.shsconferences.org/index.php?option=com_article\&access=doi\&doi=10.1051/shsconf/ 20120100206\&Itemid $=129$.

PATRON, S. (2016). Le Narrateur. Un problème de théorie narrative. Limoges: Lambert-Lucas.

PATRON, S. (ed.) (2018). Introduction à la narratologie postclassique. Les nouvelles directions de la recherche sur le récit. Villeneuve d'Ascq: Presses universitaires du Septentrion.

PHELAN, J. (1994). Present Tense Narration, Mimesis, the Narrative Norm, and the Positioning of the Reader in Waiting for the Barbarians. In: Phelan, J. \& Rabinowitz, P. J. (eds), Understanding Narrative. Columbus: The Ohio State University Press, pp. 222-245.

RICHARDSON, B. (2002). Beyond Story and Discourse: Narrative Time in Postmodern and Nonmimetic Fiction. In: Richardson, B. (ed.), Narrative Dynamics: Essays on Time, Plot, Closure, and Frames. Columbus: The Ohio State, pp. 47-63.

RICHARDSON, B. (2006). Unnatural Voices: Extreme Narration in Modern and Contemporary Fiction. Columbus: The Ohio State University Press.

RICHARDSON, B. (2011). Narrative Theory, Methodology, and the Unusual Text. In: Patron, S. (ed.), Théorie, analyse, interprétation des récits/Theory, Analysis, Interpretation of Narratives. Bern: Peter Lang, pp. 57-71.

RICHARDSON, B. (2012a). s.t. . In: Herman, D. et al., Narrative Theory: Core Concepts and Critical Debates. Columbus: The Ohio State University Press.

RICHARDSON, B. (2012b). Unnatural Narratology: Basic Concepts and Recent Work. Diegesis 1 (1), pp. 95-103. Online: https://www.diegesis.uni-wuppertal.de/index.php/diegesis/article/view/ $112 / 119$

RICHARDSON, B. (2013). Unnatural Stories and Sequences. In: Alber, J. et al. (eds), A Poetics of Unnatural Narrative. Columbus: The Ohio State University Press, pp. 16-30.

RICHARDSON, B. (2015). Unnatural Narrative: Theory, History, and Practice. Columbus: The Ohio State University Press.

RICHARDSON, B. (2016a). Unnatural Narrative Theory. Style 50 (4), pp. 385-405.

RICHARDSON, B. (2016b). Rejoinders to the Respondents. Style 50 (4), pp. 492-513.

RICHARDSON, B. (2017a). Unnatural Narrative Theory: A Paradoxical Paradigm. In: Hansen, P. K. et al. (eds), Emerging Vectors of Narratology. Berlin: De Gruyter, pp. 193-206.

RICHARDSON, B. (ed.) (2017b). Special Section on Feminist Fiction and Unnatural Narrative Theory. Storyworlds 8 (2).

RICHARDSON, B. (2018). De la narratologie non naturelle. Translation by S. Patron, based on a first version by Catherine Favier Kelly. In: Patron, S. (ed.), Introduction à la narratologie postclassique. Les nouvelles directions de la recherche sur le récit. Villeneuve d'Ascq: Presses universitaires du Septentrion, pp. 167-181.

RICHARDSON, B. (ed.) (To be published). Unnatural Narratives: Theories and Practices. Frontiers of Narrative Studies 4 (1). 
RUSHDIE, S. (1989) [1981]. Les Enfants de minuit. Translated from the English by J. Guiloineau. Paris: Librairie générale française.

RYAN, M.-L. (2006). From Parallel Universes to Possible Words: Ontological Pluralism in Physics, Narratology, and Narrative. Poetics Today 27 (4), pp. 633-674.

STYLE (2016). 50 (4).

VON CONTZEN, E. (2017). Unnatural Narratology and Premodern Narratives: Historicizing a Form. Journal of Literary Semantics 46 (1), pp. 1--23.

YACOBI, T. (1981). Fictional Reliability as a Communicative Problem. Poetics Today 2 (2), pp. 113-126.

\section{NOTES}

1. For an introduction to post-classical narratology in French, see Patron, et al. (2018). This work contains an article by Brian Richardson on unnatural narratology. A complete bibliography of works and articles is provided at the end of the article.

2. The adjective "unnatural" had already been used in this way by Richardson (see 2006, particularly p. 37 and the index p.165: "narrative, natural", "narrative, unnatural").

3. The corresponding page is currently hosted by the University of Aarhus website in Denmark, and can also be accessed from: http://projects.au.dk/narrativeresearchlab/ unnatural/.

4. See www.unnaturalnarratology.com, under the "Presentations" section (period 2008-2012).

5. The manifesto led to some significant responses (see Fludernik, 2012; Klauk \& Köppe, 2013), which in turn allowed unnatural narratologists to clarify their positions (see Alber et al., 2012 and 2013a).

6. A third major work is set to come out (see Alber \& Richardson, to be published).

7. A double issue of Poetics Today and an issue of Frontiers of Narrative Studies are also forthcoming (see Alber et al., to be published; Richardson, to be published).

8. The definition used here is the latest one provided by Richardson despite others having being offered by him and quoted more often.

9. This definition had already appeared in Nielsen's works (2010, p. 276, n. 3), but was limited to acts of narration.

10. I think it is important to add the concept of patchy time, which has gaps in it, as described in Five years of life by Mario Benedetti, where the protagonist is missing five years of his life (see Patron, 2012).

11. I borrowed this comparison from Jon-Arild Olsen (2004, p. 301). It should be remembered that the invisibility and omnimentality of Mangogul in The Indiscreet Jewels is explained by the magic powers of the ring he possesses.

12. Several articles on these subjects are forthcoming: see Alber \& Richardson (to be published). 


\section{ABSTRACTS}

The study of unnatural narratives, or unnatural narratology, is one of the latest trends that have emerged as part of post-classical narratology. This approach seems innovative and promising as it addresses several current concerns associated with theory, analysis and the interpretation of fictional narratives. It has also been intensely discussed within the narratology research community. Far from being a unified approach, unnatural narratology involves different trends, based on slightly different definitions of unnatural narratives, which sometimes lead to advocating for very different and even opposing approaches to these narratives. Unnatural narratology has already made important contributions to the study of unnatural narratives or unnatural elements within narratives that are usually neglected in established narratology or narratologies. Further investigation reveals however certain problems. A significant example of such issues is presented at the end of the article.

L'étude des récits non naturels (unnatural narratives), ou narratologie non naturelle (unnatural narratology), est l'un des derniers courants apparus au sein de la narratologie postclassique. Cette approche parait novatrice et prometteuse car elle rejoint plusieurs préoccupations actuelles associées à la théorie, à l'analyse et à l'interprétation des récits de fiction. Elle est aussi intensément discutée dans les milieux narratologiques. Loin d'être une approche unifiée, la narratologie non naturelle se compose de différentes tendances, basées sur des définitions légèrement différentes des récits non naturels, prônant des approches parfois très différentes, voire opposées, de ces récits. La narratologie non naturelle peut déjà se prévaloir d'apports importants dans l'étude des récits non naturels ou des éléments non naturels dans les récits, généralement négligés dans la ou les narratologies établies. Une étude un peu approfondie fait cependant apparaitre certains problèmes. Un exemple significatif est donné à la fin de l'article.

\section{INDEX}

Mots-clés: récits non naturels, narratologie non naturelle, récits antimimétiques, conventionalisation, approche cognitive, narrateur omniscient

\section{AUTHORS}

\section{SYLVIE PATRON}

Université Paris Diderot, Cérilac, F-75013 Paris, France 